\title{
Policing the Poachers in a Western State: Game Wardens and the Use of Discretion ${ }^{1}$
}

\author{
Stephen L. Eliason \\ Professor of Sociology \\ Department of Social Sciences and Cultural Studies \\ 1500 University Drive \\ Montana State University Billings \\ Billings, MT 59101, USA
}

Contact information: seliason@msubillings.edu

\begin{abstract}
Game wardens are specialized law enforcement officers responsible for enforcing hunting and fishing laws designed to protect wildlife resources. While performing their duties they encounter a variety of wrongdoers that range from first time offenders to those who are chronic violators of the law. Little research exists on the use of discretion by wildlife law enforcement officers, or their attitudes toward offenders. This study took a qualitative approach to data collection and examined the use of discretion by game wardens in Montana and their perceptions of habitual poachers. Factors that were associated with the use of discretion included intent of the violator, seriousness of the offense, and age of the violator. The majority of wardens in the study expressed negative opinions toward violators that were chronic offenders. Findings contribute to our understanding of law enforcement attitudes and decision making.
\end{abstract}

Keywords: discretion, game wardens, labeling, Montana, perceptions 


\section{Introduction}

While the scholarly literature about policing in urban areas is extensive, limited research has been directed toward law enforcement in rural areas, including the study of conservation law enforcement (Benoit, 1973; Calkins, 1970; Falcone, 2004; Forsyth, 1994; Forsyth \& Forsyth, 2009; Forsyth et al., 1998; Morse, 1973; Musgrave et al., 1993; Palmer \& Bryant, 1985; Thomas et al., 1999; Tobias, 1998). Game wardens, also known as conservation officers, are responsible for enforcing wildlife laws. Much of their time is spent patrolling remote rural areas including forests, lakes, and rivers to ensure that the behaviors of recreationists who are engaged in hunting and fishing activities is in compliance with the law (Crow et al., 2013; Palmer \& Bryant, 1985). In comparison to their urban law enforcement counterparts, relatively little is known about game wardens and how they enforce the law (Eliason, 2008b; Forsyth, 1993a; Forsyth, 2008).

One of the central tasks of game wardens is to apprehend violators, or poachers, who unlawfully take wildlife resources (Forsyth, 1993a; Forsyth, 2008; Palmer \& Bryant, 1985). Individuals poach for a variety of reasons, and various poacher "types" as well as motivations for poaching are described in the literature (Eliason, 2008b; Musgrave et al., 1993; Muth \& Bowe, 1998). Some poaching occurs on an infrequent basis, and includes rare and isolated events. For example, some individuals who violate wildlife laws may not plan to take wildlife illegally, but do so because an opportunity presents itself. Other poaching violations consist of deliberate and calculated acts that are performed on an ongoing basis. These poachers include chronic offenders who knowingly and purposefully choose to misappropriate fish and wildlife resources for a variety of reasons including to obtain trophies, for the money, or for the excitement. Wardens interact with all types of poachers while carrying out their duties.

In addition, as more individuals are pursuing recreational opportunities in the outdoors, crime has become a concern in these areas (Chavez \& Tynon, 2000; Pendleton, 1996; Pendleton, 1998; Pendleton, 2000; Tynon \& Chavez, 2006a; Tynon \& Chavez, 2006b; Tynon et al., 2010). A growing body of evidence suggests that the game warden occupation is changing as wardens are increasingly being asked to assume duties associated with traditional law enforcement (Falcone, 2004; Patten et al., 2015; Rossler \& Suttmoeller, 2018; Shelley \& Crowe, 2009; Sherblom et al., 2002). As with other law enforcement officers, an important part of the job for game wardens is the use of discretion (Carter, 2006; Eliason, 2003; Forsyth, 1993b).

Discretion refers to the ability of law enforcement officers to select from a variety of options in terms of deciding how to resolve law violations (Eliason, 2003). Police officers can handle criminal situations in either a formal or informal manner. In many instances, offenders are cited or arrested and officially processed in the criminal justice system. In some situations, police officers choose to give offenders a break via either a written or verbal warning. Knowledge of the factors that influence police discretion is important for developing an understanding of police 
behavior. Relatively few studies have examined the use of discretion in the context of outdoor recreation (Carter, 2006; Eliason, 2003; Forsyth, 1993b). Given the importance of natural resource protection in modern society, it is useful to develop an understanding of how those tasked with preservation of the environment perform their duties, including how they evaluate situations they encounter while enforcing wildlife laws.

Labeling theory suggests that when members of society become aware of individuals who break the law, those individuals are designated an offender and given a label, and people react toward and view offenders in terms of the label (Pfohl, 1994; Vold et al., 2002). Offenders are stigmatized as a result of the label that is applied to them. The labeling perspective has great utility for helping us understand the process by which law enforcement officers interact with offenders and create mental categories and develop attitudes toward them. When law enforcement officers deal with individuals who are known to them as persistent, chronic offenders, it is possible that it negatively affects their attitudes toward these individuals.

Knowledge of experiences with violators is essential to understanding police officer attitude formation. It is important to understand how perceptions of law enforcement officers influence their attitudes toward offenders, including those who are known as habitual offenders, since the attitudes police officers hold toward violators may influence their behavior toward these individuals.

The purpose of the present research was to contribute to the knowledge base of conservation law enforcement by identifying factors associated with the use of discretion by game wardens. In addition, given that little research has been conducted on game wardens and their attitudes toward violators, an important area of study is that of warden attitudes toward chronic offenders. Guided by the labeling theoretical perspective, this study sought to contribute to our understanding of how game wardens view chronic poachers.

\section{The study site}

Montana (see Figure 1) is a large, rural state with just over one million residents. Montana borders Canada on its north, Idaho on its west, Wyoming on its south, and both North and South Dakota on its east. In terms of land area, it is the fourth largest state in the United States. The geography and terrain is diverse and includes rugged mountains in the western part of the state, while the eastern areas are characterized by vast sweeping plains. Abundant wildlife resources are found throughout the state. Fishing and hunting are popular recreational activities for both residents and nonresidents (Baginski \& Biermann, 2010; Eliason, 2008a; Gude et al., 2012; Schorr et al., 2014). State game wardens are employed by Montana Fish, Wildlife and Parks, the state agency responsible for conserving wildlife resources. Game wardens are responsible for enforcing hunting and fishing laws in the state. Their activities have received attention in the 
media in recent years with the "Wardens" television show (Montana Fish, Wildlife and Parks, 2011).

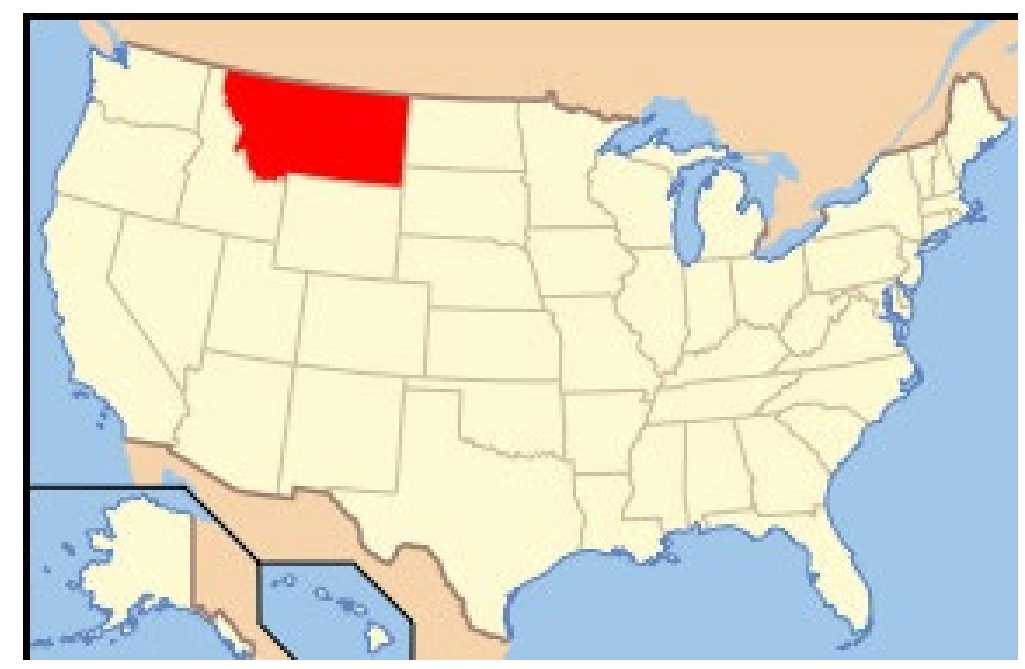

Figure 1: Montana

\section{Methods}

This study took a qualitative approach to data collection. A mail survey was sent to all game wardens in Montana. The survey contained mostly open-ended questions about the job of game warden. Neuman (2011, pp. 324-325) stated: “To learn how a respondent thinks and discover what is important to him or her...open questions are best. ...Open-ended questions are especially valuable in early or exploratory stages of research." Henderson (2006, p. 48) stated:

The meanings of any symbol (e.g., leisure) have their origins in interactions, which are defined and changed by individuals according to the meanings that are held. The individual studied is the expert and the attempt is to describe their vocabularies, ways of looking, and sense of the important and the unimportant.

The author obtained a list of game wardens from Montana Fish, Wildlife and Parks $(\mathrm{N}=$ 84 ) in 2004. A survey was sent to all of the wardens in February 2005, and twenty-two surveys were returned, for a response rate of $26 \%$. To obtain information about game warden discretion, the survey contained the question: "Do you use discretion when citing violators? If yes, describe."

A question designed to elicit game warden perceptions of chronic poachers was also included: "If someone comes to be known as a habitual wildlife law violator or "poacher," does 
it affect your attitude toward them? If yes, describe." Game wardens were given the opportunity to provide responses in their own words so their reasons for using discretion and their perceptions of habitual poachers could be obtained in rich detail.

Data for the study consisted of game warden responses to the questions about use of discretion and perceptions of habitual poachers. For data analysis, the author examined all of the warden comments to these questions, and categorized responses according to common themes that emerged from the analyses. Summarization and interpretation of game warden comments is provided by the author.

\section{Results and Discussion}

All of the game wardens in the present study were male, and they had an average age of 42 years old. These individuals had an average of nearly seventeen (16.76) years of experience working in wildlife law enforcement.

To obtain information about the use of discretion, wardens were asked the question: "Do you use discretion when citing violators? If yes, describe." Twenty of the twenty-two wardens who returned the survey indicated that they used discretion when citing violators. Two wardens did not provide a response to the question.

\section{Use of Discretion}

Some of the wardens provided general comments that alluded to the importance of discretion for carrying out the duties of their occupation. These comments indicate that wardens routinely encounter a variety of situations in the field that have differing circumstances that they believe need to be taken into account by an officer:

"Consider all aspects like: honest mistake, first offense, etc. Situations are not always black and white. We must investigate a situation before ever writing a warning or citation."

"Hunting violations are not always clear cut - there's usually a lot of variables to take into consideration."

"Yes, the world is not black and white."

"Yes, that is our job. Wardens learn that and get real good at it. Experience, experience, experience. [There is] no substitute!"

"Yes, I seldom cite for all violations."

"I try and be fair and treat everyone the same and I don't issue multiple citations." 


\section{Intent of the Violator}

The most common factor associated with the use of discretion in the study was the intent of the violator. Wildlife offenses are generally classified as "strict liability" crimes, which means an individual can be cited and held accountable for an offense whether or not he or she intended to commit the infraction (Eliason, 2003, p. 133). Nonetheless, a number of game wardens in the present study indicated that they took the intent of the violator into account when determining how to resolve the situation as the following comments reveal:

"I determine the intent of the violator. Unintentional vs. intentional. Age is also a factor as well as what other factors are present."

"Real intent. Folks that make a mistake and turn themselves in are to get the least punishment by my recommendation."

"I try to ascertain if it was an honest mistake, was the person truthful about what happened, do I feel they may do it again/have they done this before. A person who made an honest mistake, was truthful, and is not likely to repeat the mistake will likely get a break."

"Knowing when a person made a mistake and when a deliberate act or violation has occurred can be the hardest decision a warden makes. The average warden writes 45 citations a year. Compare that to any other law enforcement."

"I look for intent and, or should they have known different. Attitude post violation plays a role as well. Whether or not they are truthful throughout the process will also determine to what extent I use discretion or not."

\section{Seriousness of the Offense}

The seriousness of an offense has been identified as an important factor associated with the use of discretion in wildlife law enforcement (Carter, 2006; Eliason, 2003; Forsyth, 1993b). Consistent with prior research on game warden discretion, the responses from two wardens indicated that seriousness of the offense played an important role in terms of how they treated a violator:

"When a violator may have killed multiple animals violating multiple laws I will typically address the most serious with charges and the less serious with written warnings - it is a social acceptance more so than the correct way."

"I don't "stack tickets" except in extreme abuse cases."

\section{Age of the Violator}

Responses of wardens in the present study revealed that some of these individuals took the age of the violator into account when determining how to resolve situations. 
"[It is] hard to describe, but I try to give kids a break and in general do what's best for the resource, the department and the people of Montana."

"Sometimes - age, violation type, repeat offenders, etc."

\section{Educating the Offender}

Comments provided by a couple of wardens indicated that they wanted offenders to learn from their experience, and the use of discretion was important in determining what response to the situation would be most likely to result in achieving that objective:

"Having the discretion to choose what level of education a person needs to receive to change their behavior is very important. If a person commits 3 illegal acts and needs 3 citations to address the problem then a warden should issue 3 , but if one citation will/would do the job just issue one!"

"I try to use some situations as an educational moment. Some people do make honest mistakes."

\section{Honesty}

Comments from wardens indicated that honesty was related to the use of discretion. A couple of wardens mentioned that they were more likely to go easier on individuals who were honest with them about their offense:

"I encounter honesty so seldom, I always reward it. I try to involve [the] prosecutor to provide a deal if the subject is willing to provide information on "bigger" players." "[I] try to give honest people a break if [they are] deserving."

\section{Perceptions of Habitual Poachers}

To obtain information about their perceptions of habitual poachers, game wardens were asked "If someone comes to be known as a habitual wildlife law violator or "poacher," does it affect your attitude toward them? If yes, describe." A total of nineteen wardens provided a response to the question. The majority of wardens (sixteen, $84.21 \%$ ) responded "yes," one $(5.26 \%)$ responded "no," and two $(10.53 \%)$ provided responses that fell into a category designated as "other." 


\section{No Respect for Habitual Violators}

Comments from some of the wardens indicated that they had no respect for chronic offenders of wildlife laws. This is because they felt that the actions of these individuals were deliberate, ongoing, and demonstrated a lack of concern for wildlife resources:

"Yes. I think less of them because they do not respect and revere the resource. A habitual poacher does not make a mistake because of poor judgement, etc. They make calculated decisions to take the risk of poaching."

"Yes. It is hard to trust or respect someone who continually abuse[s] the resources you work hard to protect!"

"Yes, they go against my personal value system and belief. I believe a person can make mistakes but one who habitually offends makes the choice to do wrong to the detriment of an honorable tradition."

"Yes. They get zero respect from me."

"Yes. Because they will not stop."

"Yes, [it] depends on whether or not they acknowledge their mistakes."

\section{Stealing the Resource}

A number of wardens in the study felt that the criminal behavior of habitual offenders was morally wrong and had a deleterious impact on wildlife resources. As the following comments suggest, they held negative attitudes toward these offenders:

"Yes. This person is affecting all the game for everyone now and in the future.

He is stealing from all of us. He needs to be stopped somehow. My attitude would become more hardened against the person."

"Yes. This type of individual usually is very hard on the resource. They generally show no respect for law enforcement authorities and typically are also violating many other regulations as well. Motor vehicle, Forest Service use violations, etc."

"These people don't care about the wildlife resource and have no ethics."

"Absolutely. They not only disrespect the resource but also the legal sportsman."

\section{Work The Offender Harder}

Some of the wardens indicated that when they become aware that certain individuals were habitual offenders, they would enhance their enforcement efforts toward those individuals. This is a logical response on the part of wardens. Direct knowledge of past involvement in criminal activity by offenders is likely to result in law enforcement officers paying close attention to the activities of those individuals in the future: 
"No, it just makes me work harder in stopping them."

"Yes. I will work them harder."

"Yes, they receive more scrutiny when dealt with in the field."

"Yes. [I] prioritize checking their compliance."

\section{Avoid Them/Their Business}

The comments from a couple of wardens suggested that if they know someone is a habitual poacher, they will not become friends with them, and one of the wardens indicated that if an offender runs a business in the local community he will deliberately avoid it:

"Yes. I won't patronize their business. They remain an acquaintance, never [a] friend."

"Absolutely. I try not to associate in any way other than professional obligations and requirements."

\section{Other}

One warden indicated that his attitude toward habitual poachers was affected by how a particular poacher felt toward him, and indicated that these individuals had the potential to become good informants:

"It depends on their attitude toward me. I try not to judge. I have friends who are poachers. All my best informants are reformed poachers."

Comments from another warden stressed that although his attitude toward habitual poachers was not affected by their reputation, he did feel that it influenced the attitude of the court toward these offenders:

'Not my attitude, but the court system's. I haven't had to deal a lot with habitual offenders, they tend to avoid Fish and Game personnel."

\section{Conclusion}

The findings of this study contribute to our understanding of the wildlife law enforcement profession, and enhance our knowledge of game wardens and the decision making practices they carry out in the performance of their job. The results suggest that the use of discretion by game wardens is a complex process that is influenced by a variety of factors. Given the variety of situations they encounter in the field, wardens stressed the importance of discretion for them in order to successfully carry out their job. Although wildlife offenses do not require intent on the 
part of a violator in order to be cited or to obtain a conviction (Eliason, 2003), intent of the violator was related to the use of discretion by wardens and was the most frequently mentioned factor in the present research. In addition, other factors such as seriousness of the offense, age of the violator, and honesty were also associated with the use of discretion.

Findings of this research enhance our understanding of conservation law enforcement officers' reactions and attitudes toward habitual offenders. The majority of wardens in the study indicated that if they recognize a wildlife law violator as a habitual offender, it affects their attitude toward that individual. This is consistent with labeling theory, which posits that as someone comes to be identified as an offender it influences the perception of other people and they react toward the offender in accordance with the label (Pfohl, 1994; Vold et al., 2002). The label of "poacher" is negative and carries a stigma, but when someone gets identified by wardens as a "habitual poacher" or "chronic poacher" the label is especially stigmatizing and the activities of those individuals receive greater scrutiny by wardens (Eliason, 2003).

To broaden our knowledge base of wildlife law enforcement, future research should examine use of discretion by game wardens in other geographical contexts to determine if there are regional variations. Also, it would be beneficial for future studies to determine if there are differences in the use of discretion by age of the officer. That is, are older wardens with more law enforcement experience more likely to use discretion than younger wardens who are less experienced and fresh out of the police academy?

Future research should also examine game warden attitudes toward offenders by years of service. Do wardens with more occupational experience become cynical and have more negative attitudes toward offenders than newer officers? This is becoming more important in the context of change in conservation law enforcement as these officers become more like traditional law enforcement officers in terms of the responsibilities they are given (Falcone, 2004; Patten et al., 2015; Rossler \& Suttmoeller, 2018; Shelley \& Crow, 2009; Sherblom et al., 2002). It is hoped that this research will generate additional interest in the study of conservation law enforcement by law enforcement scholars. 


\section{Endnote}

${ }^{1}$ Acknowledgements: This research was funded by an Internal Grant from the Research and Creative Endeavors Committee at Montana State University Billings (\# F2004-09).

${ }^{2}$ Map source: https://search.creativecommons.org/photos/f451a258-66eb-4990-bbef$\underline{\text { ed48dcef6871 }}$

\section{References}

Baginski, J., \& Biermann, C. (2010). Montana on the fly: A state hooked on trout. Focus on Geography, 53(4), 142-147. https://doi.org/10.1111/j.1949-8535.2010.00017.x

Benoit, P. J. (1973). From fish and wildlife officer to environmental conservation officer. Wildlife Society Bulletin, 1(3), 128-130.

Calkins, F. (1970). Rocky mountain warden. Alfred A. Knopf.

Carter, T. J. (2006). Police use of discretion: A participant observation study of game wardens. Deviant Behavior, 27(6), 591-627. https://doi.org/10.1080/01639620600781555

Chavez, D. J., \& Tynon, J. F. (2000). Triage law enforcement: Societal impacts on national forests in the west. Environmental Management, 26(4), 403-407. https://doi.org/10.1007/s002670010097

Crow, M. S., Shelley, T. O., \& Stretesky, P. B. (2013). Camouflage-collar crime: An examination of wildlife crime and characteristics of offenders in Florida. Deviant Behavior, 34(8), 635-652. https://doi.org/10.1080/01639625.2012.759049

Eliason, S. L. (2003). Throwing the book versus cutting some slack: Factors influencing the use of discretion by game wardens in Kentucky. Deviant Behavior, 24(2), 129-152. https://doi.org/10.1080/01639620390117219

Eliason, S. L. (2008a). A statewide examination of hunting and trophy nonhuman animals: Perspectives of Montana hunters. Society and Animals, 16(3), 256-278. https://doi.org/10.1163/156853008X323402

Eliason, S. L. (2008b). Wildlife crime: Conservation officers' perceptions of elusive poachers. Deviant Behavior, 29(2), 111-128. https://doi.org/10.1080/01639620701457808 
Falcone, D. (2004). America's conservation police: Agencies in transition. Policing: An International Journal of Police Strategies and Management, 27(1), 56-66. https://doi.org/10.1108/13639510410519912

Forsyth, C. J. (1993a). Chasing and catching 'bad guys': The game warden's prey. Deviant Behavior, 14(3), 209-226. https://doi.org/10.1080/01639625.1993.9967940

Forsyth, C. J. (1993b). Factors influencing game wardens in their interaction with poachers: The use of discretion. Free Inquiry in Creative Sociology, 21(1), 51-56.

Forsyth, C. J. (1994). Bookers and peacemakers: Types of game wardens. Sociological Spectrum, 14(1), 47-63. https://doi.org/10.1080/02732173.1994.9982051

Forsyth, C. J. (2008). The game of wardens and poachers. Southern Rural Sociology, 23(2), 4353.

Forsyth, C. J., \& Forsyth, Y. A. (2009). Dire and sequestered meetings: The work of game wardens. American Journal of Criminal Justice, 34(3-4), 213-223. https://doi.org/10.1007/s12103-009-9065-3

Forsyth, C. J., Gramling, R., \& Wooddell, G. (1998). The game of poaching: Folk crimes in Southwest Louisiana. Society and Natural Resources, 11(1), 25-38. https://doi.org/10.1080/08941929809381059

Gude, J. A., Cunningham, J. A., Herbert, J. T., \& Baumeister, T. (2012). Deer and elk hunter recruitment, retention, and participation trends in Montana. Journal of Wildlife Management, 76(3), 471-479. https://doi.org/10.1002/jwmg.272

Henderson, K. A. (2006). Dimensions of choice: Qualitative approaches to parks, recreation, tourism, and leisure research. Venture Publishing.

Montana Fish, Wildlife and Parks. (2011). Law enforcement reality show "WARDENS” to debut on Outdoor Channel. Retrieved June 23, 2011, from:

$<$ http://fwp.mt.gov/news/newsReleases/headlines/nr_3932.html $>$.

Morse, W. B. (1973). Law enforcement--One third of the triangle. Wildlife Society Bulletin, 1(1), 39-44.

Musgrave, R. S., Parker, S., \& Wolok, M. (1993). The status of poaching in the United States: Are we protecting our wildlife? Natural Resources Journal, 33(4), 977-1014. 
Muth, R. M., \& Bowe, J. F. (1998). Illegal harvest of renewable natural resources in North America: Toward a typology of the motivations for poaching. Society and Natural Resources, 11(1), 9-24. https://doi.org/10.1080/08941929809381058

Neuman, W. L. (2011). Social research methods: Qualitative and quantitative approaches. Allyn \& Bacon.

Palmer, C. E., \& Bryant, C. D. (1985). Keeper's of the king's deer: Game warden's and theenforcement of fish and wildlife law. In C. D. Bryant, D. W. Shoemaker, J. K. Skipper, Jr., \& W. E. Snizek (Eds.), The Rural Workforce: Non-Agricultural Occupations in America (pp. 111-137). Bergin \& Garvey.

Patten, R., Crow, M. S., \& Shelley, T. O. (2015). What's in a name? The occupational identity of conservation and natural resource oriented law enforcement agencies. American Journal of Criminal Justice, 40(4), 750-764. https://doi.org/10.1007/s12103-014-9286-y

Pendleton, M. R. (1996). Crime, criminals and guns in "natural settings": Exploring the basis for disarming federal rangers. American Journal of Police, 15(4), 3-25. https://doi.org/10.1108/07358549610151799

Pendleton, M. R. (1998). Policing the park: Understanding soft enforcement. Journal of Leisure Research, 30(4), 552-571. https://doi.org/10.1080/00222216.1998.11949847

Pendleton, M. R. (2000). Leisure, crime and cops: Exploring a paradox of our civility. Journal of Leisure Research, 32(1), 111-115. https://doi.org/10.1080/00222216.2000.11949897

Pfohl, S. (1994). Images of deviance and social control: A sociological history. McGraw-Hill.

Rossler, M. T., \& Suttmoeller, M. J. (2018). Is all police academy training created equally? Comparing natural resource officer and general police academy training. Police Journal, 91(2), 107-122. https://doi.org/10.1177/0032258X17692164

Schorr, R. A., Lukacs, P. M., \& Gude, J. A. (2014). The Montana deer and elk hunting population: The importance of cohort group, license price, and population demographics on hunter retention, recruitment, and population change. Journal of Wildlife Management, 78(5), 944-952. https://doi.org/10.1002/jwmg.732 
Shelley, T. O., \& Crow, M. S. (2009). The nature and extent of conservation policing: Law enforcement generalists or conservation specialists? American Journal of Criminal Justice, 34(1-2), 9-27. https://doi.org/10.1007/s12103-008-9057-8

Sherblom, J. C., Keränen, L., \& Withers, L. A. (2002). Tradition, tension, and transformation: A structuration analysis of a game warden service in transition. Journal of Applied Communication Research, 30(2), 143-162. https://doi.org/10.1080/00909880216579

Thomas, J. K., Adams, C. E., \& Wang, G. (1999). Law enforcement personnel needs of a state natural resource agency. Human Dimensions of Wildlife, 4(1), 1-19. https://doi.org/10.1080/10871209909359141

Tobias, M. (1998). Nature's keepers: On the front lines of the fight to save wildlife in America. John Wiley \& Sons.

Tynon, J. F., \& Chavez, D. J. (2006a). Adapting a tourism crime typology: Classifying outdoor recreation crime. Journal of Travel Research, 44(3), 298-307. https://doi.org/10.1177/0047287505278986

Tynon, J. F., \& Chavez, D. J. (2006b). Crime in national forests: A call for research. Journal of Forestry, 104(3), 154-157.

Tynon, J. F., Chavez, D. L., \& Baur, J. W. R. (2010). Crime in the woods: Role of law enforcement officers in national forests. Managing Leisure, 15(4), 251-263. https://doi.org/10.1080/13606719.2010.508665

Vold, G. B., Bernard, T. J., \& Snipes, J. B. (2002). Theoretical criminology. Oxford University Press. 